\title{
The Effect of Managers Strategic Thinking on Opportunity Exploitation
}

\author{
Mehdi Tajpour \\ Ph.D. candidate, Faculty of Entrepreneurship, Tehran University, Tehran, Iran \\ Elahe Hosseini \\ Ph.D. candidate, Faculty of Management, Yazd University, Yazd, Iran \\ Atefe Moghaddm \\ MA. Faculty of Management, Shiraz University, Shiraz, Iran.
}

\begin{abstract}
In today's world, successful managers are those who are able to understand and exploit the opportunities in order to adapt to the environmental changes. Understanding an opportunity starts with a phenomenon that stimulates the mind. Many phenomena contain the opportunity but we can't recognize it because our mind is not sensitive to that. As there has been no general research on managers strategic thinking effect on opportunity exploitation, this study copes with investigating managers strategic thinking effect on opportunity exploitation. The statistical population of the present study includes 150 technical managers of the travel and tourism agencies and companies. According to the Cochran formula, the sample size was achieved and it was 50 people. Among the items related to the managers strategic thinking, the variable of opportunities and threats recognition rate for internal-external environment, and the variable of clients' opinion importance (within and out of organization) in decision making are the first and second priorities, respectively. Among the items related to the opportunities exploitation variable, studying measure variable and the variable of paying attention to the favourable organizations in order to make decision in management and the effect measure of factors such as the entrepreneur alertness, social networks and personality characteristics on opportunity recognition are the first and the second priorities, respectively.
\end{abstract}

KEYWORDS: Strategic Thinking, Opportunity, Opportunity Exploitation

\section{Introduction}

Organizations don't live in the vacuum. They work in an environment which forms their behavior and structure(Deghani, Nahand, \& Ve Moghni, 2015). The changes and their speed are the most important components in the environment. Organizations usually face a huge amount of change which creates various situations such as opportunities and threats for them. (Ghafarian et al, 2010). Clemons describes the business environment of the $21^{\text {st }}$ century with the characteristics such as destructive changes, fleeting opportunities, uncertainty and disorder in Harvard University Journal. In chaotic situations, the play rules change consistently and have no sustainable advantage for the organization except the continuous adaptation to the environment. Adapting to the environment means changing the organization features for an advantageous and efficient function in special environmental situations. (Ghafaryan et al, 2010).Nevertheless, the bright strategy is the main need of any organization. Organizations should have a clear view on how they intend to distinguish their productions and services from other competitors for their various customers 
otherwise they will be swallowed alive in the highly competitive environment. Previously, success was possible because there were not many competitors and companies. But nowadays, old strategies are rejected fast and cruelly. Therefore, organizations should find a way to create and grow opportunities instead of reducing or eliminating the loss(Schaper, Volery, Weber, \& Gibson, 2014). As mentioned previously, in today's world, successful managers are those who are able to understand and exploit the opportunities in order to adapt to the environmental changes. The strategic thinking was presented in early 1990s because the classical approaches of strategy planning were not able to predict and create the future in the area of management literature(Bouhali, Mekdad, Lebsir, \& Ferkha, 2015). From Heracleous point of view, strategic thinking is to create new and innovative guidelines which can rewrite the play rules and draw a potential view for the future that is significantly different from now(Heracleous, 1998). Ghafarin and Kiani also introduce strategic thinking as an insight and comprehension that helps the human being to realize which factors are effective to achieve success and which factors are not. ( Ghafarian et al, 2010).

Thinking strategy is an important instrument and nowadays the CEOs should be equipped with this instrument. It's known as a trump card in social and economic arenas and it enables managers to evaluate the risk, profit and the expenses due to their decisions. Strategic thinking looks at the strategy as an art more than a processual and methodological aspect and it's known as a suitable approach for the organization leadership in today's changeable and not predictive environment. This approach may create an advantage for the organization(Arayesh, Golmohammadi, Nekooeezadeh, \& Mansouri, 2017). In the new era, the strategy planning has been expired and its role is passed to strategic thinking. There is a more constructive and advantageous approach in this area. Thinking and strategy planning can have a complementary role. In this approach, thinking creates the prospect and the strategy planning is used to explain and exploit that prospect(Arayesh et al., 2017).As some researchers have defined the strategic thinking as an "insight and knowledge about the current situation to exploit the opportunities", it can be said that having the strategic thinking is a way to recognize the opportunities. Because an insight or a good knowledge of the current situation helps managers recognize the market facts and its rules and it also helps them create new and valuable strategies. In this study, we investigate how effective it is for organization managers to have strategic thinking for exploiting the opportunities.

\section{Theoretical Framework}

\section{Strategic Thinking}

Although it's been two decades since strategic thinking theory was presented in the strategic area, the literature has mostly been theoretical and based on concept development and there has been few experimental research in this area(Haines, 2016). Although strategic thinking concept has existed in literature for more than a quarter century, it has been applied inappropriately instead of other aspects of developing organizational direction such as "strategy", "strategy management", "strategy planning"(Liedtka, 1998). This problem has two origins: 1. The difference between theoreticians on how to create organization strategies, 2. Lack of a clear definition about strategic thinking in theoretical background(Goldman \& Casey, 2010). Bonn(2005)believes that the existing gap in definition of strategic thinking results from not understanding this general concept and from limited development among organization leaders(Bonn, 2005). Strategic thinking is longer, more abstract and more problem- oriented in comparison with thinking operation and its components are learnt reflectively not practically(Goldman \& Casey, 2010). Other theoreticians combine the individual views and present strategic thinking as actions such as systematic view, strategy determination, genius use of opportunity, thinking during the time framework, hypothesis approach and test(Liedtka, 1998). Abraham(2005) believes strategic thinking sounds like identifying sustainable strategies or business models that are represented to the valued customers. Strategic thinking is the process of finding alternative ways to compete in creating value for the customers. Therefore, we can define strategic thinking as the alternative way or business models that creates value for the customers(Abraham, 2005). The person who thinks about the strategic thinking (to develop strategy), does the activities to develop strategy such as investigation, asking 
question, conceptualization and test(Goldman \& Casey, 2010). After investigating literature and background, Golman \& Casy, (2010) defined the strategic thinking as: conceptual thinking, system-oriented, directional and opportunity-oriented which leads to new and imaginative organizational strategies.

\section{Strategy Entrepreneurship}

Exploiting the entrepreneurial opportunities assists enterprise in trying to form a competitive advantage and to create wealth. Many enterprises fail to motivate individuals to follow entrepreneurial opportunities; therefore, the competitive advantage of the enterprise is failed(Day $\&$ Wendler, 1998). Entrepreneurs may identify the opportunities and exploit them so that it leads to create a temporary advantage instead of a sustainable advantage. It happens when entrepreneurs are not successful in resources strategy management; therefore, developing the competitive and permanent advantage faces problems(Hitt, Ireland, Camp, \& Sexton, 2001).As a result, both opportunity-related (e.g. entrepreneurship) and advantage-related (e.g. strategy management) behaviors are necessary to create wealth but only one is not enough(Amit \& Zott, 2001).

Hitt et al (2001) and Ireland et al (2003) mention that strategy entrepreneurship consists of entrepreneurial actions with strategic approach. Enterprises can identify the opportunities, but they are not able to exploit; therefore, the potential wealth is not created and Beneficiaries won't achieve their rights. As a result, enterprises who own the competitive advantage but are not able to identify new opportunities, face dangers (such as market change that may destroy wealth creation or even reduce the continuous wealth creation) from beneficiaries.

Wealth is created when the enterprises combine the efficient behavior of opportunism (entrepreneurship) with the efficient behavior of seeking advantage (strategy management)(Ireland et al, 2003).

\section{Strategic Thinking Elements}

Takor mentioned that strategic thinking consists of features such as being active, risk-taking, central control and power communications(Robinson, 2012). Liedtka mentions Strategic thinking elements in a conceptual article that contains systematic view, thinking during the time, intentionality and optimism. She refers these elements help the organization to be flexible toward changes and they will also have good results for the organization(Liedtka, 1998). She also refers that only individuals have the ability of strategic thinking and the organizations can only pave the way to the strategic designing systems.

Abraham believes that the effective factors on upgrading strategic thinking are attempt for entrepreneurship, finding new opportunities, futurism, cooperation and being different. Being different means to do current affairs of the organization in different ways(Abraham, 2005).

Bonn considers three features necessary for the strategic thinking:

1. General understanding of organization and its environment and reminding the communications and the complexity of infrastructures and relations

2. Creativity, new innovations and applying old ideas again

3. A prospect for the organization future

Liedtka added the following items to the Bonn's features(Liedtka, 1998):

1. Having a direction which is not necessarily in accordance with the available resources or the current opportunities.

2. Thinking during the time, looking forward to future and considering the past, now and their relations.

3. Being hypothesis- oriented or asking the question "what if?" which is a kind of intuitiveanalytic activity. 
Liedtka defines the strategic thinking as a special method with special features. From her point of view, the strategic thinking elements are:

1. Systematic thinking: strategic thinking, has a conceptual model of creating value general system in mind and understands the dependences in the chain. The systematic thinking assists in clearing up the individuals' role in the bigger system and enables them to find their behavior effect on other parts of the system and the final result. This approach investigates the proportions of company, business and functional levels of strategy and also the individual level.

2. Strategic determination means the solid inner determination in order to achieve goals and focuses on making the strategies oriented and strong.

3. Making progress according to the approach is a science whose aim is increasing the ability of creative hypothesizing and examining the hypothesis.

4. Intelligent opportunism: consists of being intelligent about the environment and paying attention to the business changes and the resulting opportunities.

5. Thinking during the time: according to the past, considering the present and looking forward to future, we should always have contemporary thinking.

In this study, the existence or lack of strategic thinking among managers has been investigated according to Liedtka strategic thinking elements categorization.

\section{Opportunity}

Opportunity is the idea or dream discovered or created by an entrepreneurial organization and gradually it is possible to show its potential profitability by investigation(Short, Ketchen Jr, Combs, \& Ireland, 2010). The key to entrepreneurial success is to recognize considerable opportunities (the vacuum between the market needs and available solutions is considerable) and to understand these opportunities exactly. Nevertheless, imagining the future scenarios is needed to understand an opportunity(Simon, Bumpus, \& Mann, 2012). Tangible opportunities appear when there is a vacuum between the market needs and the tools to meet those needs. Entrepreneurs identifies entrepreneurial opportunities through a comprehensive process and based on their conclusion from the market needs and the tools to meet them(Simon et al., 2012).

\section{Opportunity Recognition and Exploitation}

\section{Entrepreneurial Opportunities Recognition:}

The importance of entrepreneurial opportunities Recognition has been mentioned in many entrepreneurship studies as a vital element of entrepreneurial behavior and one of the main concepts of entrepreneurship definition and is known as the heart of entrepreneurship(Lehner \& Kansikas, 2012; Tang, Kacmar, \& Busenitz, 2012; Tumasjan \& Braun, 2012). Opportunity Recognition is known as one of the most important abilities of entrepreneurs(Casillas, Moreno, \& Barbero, 2010). Opportunities Recognition is a process by which it is possible to create a new and profitable business, production or service for the individual(Zeidan \& Bahrami, 2011). Sarasvati et al, (2003) in their categorization of opportunities, defined the opportunities Recognition as: if both supply and demand are clear, the opportunity to put them together should be "recognized" and there should be an arrangement between the supply and demand. Therefore, the opportunities can be exploited by both existing enterprise and founding a new one. A good example is contracts and giving dealership. Corbett, (2007) defined the opportunities Recognition as the ability to recognize a good idea and to transfer it to the business in a way that creates added value and income. Baron \& Shane (2005) believe that opportunities Recognition is a process during which people conclude that they have a potential to create something new with the capacity of creating economic value. From Gundry \& Kichul point of view, opportunities Recognition is a process by which entrepreneurs seek, hold and refine new ideas that lead to business opportunities. Opportunities discovery and identification is not just limited to finding valuable productions. It also consists of identifying market, production material, production method, and organizing methods. These fields 
need a vast knowledge that is not available to one person(Hsieh, Nickerson, \& Zenger, 2007).Pokoha (2010) mentioned that entrepreneurial opportunities recognition consists of dimensions such as competitive dynamics that are about data collection and analyses; the pioneer opportunism of the future which is related to a brief image of the future; and making an innovative guideline to create opportunity which is related to different economic activities. Many researchers have emphasized the opportunity recognition and opportunity exploitation in premier steps of creating and establishing a new business and have considered it important. New opportunities are the main and necessary elements to form entrepreneurial activities and creating a new organization to achieve entrepreneurial goals is vain without opportunity(Ramos-Rodríguez, Medina-Garrido, Lorenzo-Gómez, \& Ruiz-Navarro, 2010). In entrepreneurship literature, what is known as "opportunity recognition", includes three different steps:

- Feeling or understanding the market needs or unused resources;

- Recognizing or discovering a new "proportion" between the special market

- Creating a new "proportion" between the needs and resources that have been separated in forming the concept of a business.

These processes are understanding, discovering and creation, respectively and show the recognition(Ardichvili, Cardozo, \& Ray, 2003).

\section{Opportunity Exploitation}

Mc Milan et al, (1986) define the opportunity exploitation as 'building efficient and perfect operations for the identified productions and services". For most entrepreneurs, exploiting opportunity is a necessary step to earn income and finally to create a successful business. March(1991) and Rice (2002) believe that venture starts with discovering a new business opportunity. During the discovering, entrepreneurs try to improve their knowledge about technology and market by collecting information resulting from experiment and search. (such as market research around customer demand and development and examining technology)(Choi \& Pavelka, 2012). Opportunity exploitation consists of elements such as resource-oriented approach, the high knowledge of market and technology, high capacity of management and supporting shareholders who exploit them(Shepherd, 2016). Companies and Mc Mullen (2007) believe that we should recognize the opportunities before exploiting them. Opportunities are generally divided into three categories; economic opportunities, cultural opportunities and socio- political opportunities. Each category is divided in two subcategories. Therefore, it is necessary to identify the six subcategories of entrepreneurial opportunities based on supply and demand. Economic opportunities are divided into technological opportunities and market opportunities. Technological opportunities lead to creating new commodities and services and market opportunities lead to commercializing these commodities and services in order to create wealth. In the same way, identifying cultural opportunities are divided in the value chain according to their own resources. Producer opportunities, consumer opportunities and finally socio-political opportunities result from dominant network structures including opportunities out of political events and opportunities in political lobbying strategies(Balls, 2013).

\section{Empirical Background}

Armando \& Roberta (2015) in a theoretical research "strategic thinking and business innovation", presented a theoretical model of strategic thinking that showed strategic thinking is the leader of a cognitive process. There have been limited studies on strategic thinking in Iran. Moamayi et al (2014) concluded that university chancellors are faithful to strategic thinking. Systematic thinking is mostly used among the chancellors of Tehran medical science and healthcare university headquarters and is less used in intelligent opportunism. Monavarian et al (2013) mentioned that considering the important actions by Tehran Municipality such as formulating strategy documents, there is a sensible distance between strategic thinking main factors importance and the current situation of managers. Tabatayi Jafari (2011) concluded that in Poly Pack company, two components of systematic thinking and intelligent opportunism are practical at the good level, two 
components of being meaningful and punctual thinking at the low level and hypothesizing component is practical at the very low level. Farzin Abdeh (2010) stated that considering the systematic thinking factors, in Behnoush factory, thinking is applied at a good level. According to the mentioned literature, the conceptual model of research and hypotheses was designed and formulated:

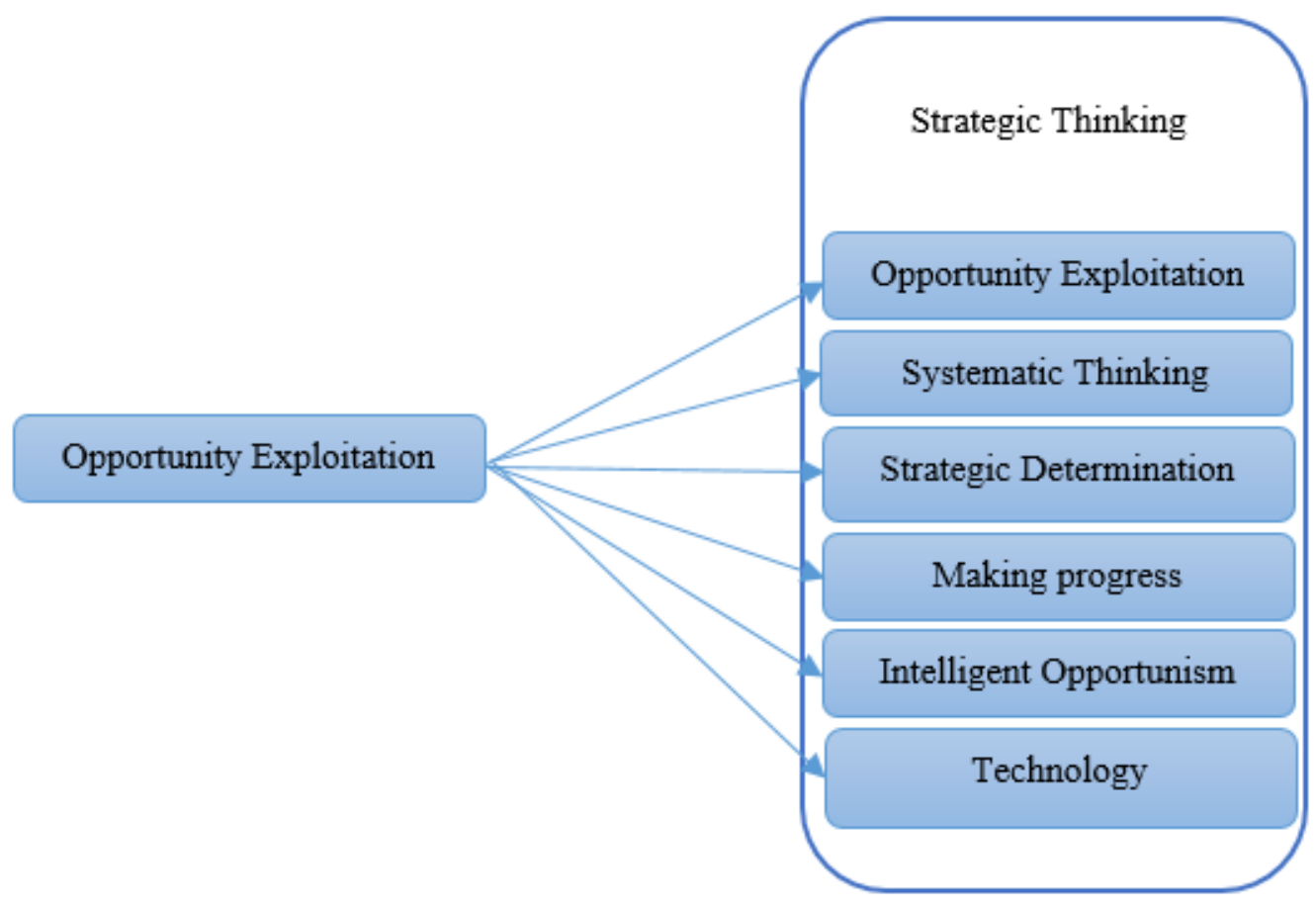

Figure 1: Conceptual Model of Research

\section{Main Hypothesis}

Strategic thinking has an effect on opportunity exploitation.

\section{Sub-hypotheses}

1. Systematic thinking has a positive and sensible effect on opportunity exploitation.

2. Strategic resolution has a positive and sensible effect on opportunity exploitation.

3. Advancing has a positive and sensible effect on opportunity exploitation.

4. Intelligent opportunism has a positive and sensible effect on opportunity exploitation.

5. Technology has a positive and sensible effect on opportunity exploitation.

\section{Methodology}

This research is practical based on its purpose and a survey based on its data collection method. The instruments are questionnaire and the Likert five points scale was used. It means that by the help of reviewing the texts and literature related to the effect of strategic thinking on entrepreneurial opportunities exploitation and by the use of the research mode, the questionnaire is prepared, the main variables are determined and the instruments of quantitative data collection are finalized. The quantitative data has been collected and analyzed and the data generalization 
possibility has been tested. The statistical population of the present study includes 150 technical managers of the travel and tourism agencies and companies in Tehran. According to the Cochran formula, the sample size was achieved and it was 50 people. The experts' opinion was used for the reliability of the research. This research was studied and reviewed by two experts and some tips were given to adjust or to change the questionnaire. In order to prove the validity of the research, the Cronbach Alpha Coefficient was used and 79\% was achieved in different parts of the questionnaire which is known acceptable. The SPSS software was used to analyze the data by descriptive-deductive statistics (Chi-Square test and Friedman test) in accordance with the research goals.

\section{Data Analyses}

1. Individual characteristics of the sample

Table1. Frequency Distribution of the Respondents Based on individual characteristics $(\mathrm{n}=50)$

\begin{tabular}{|c|c|c|c|c|}
\hline Features & Average & Standard & Minimum & Maximum \\
& & Deviation & & \\
\hline Age (years) & 38.80 & 11.199 & 24 & 30 \\
\hline Experience(years) & 13.12 & 7.230 & 3 & 30 \\
\hline
\end{tabular}

The descriptive analyses of the respondents' individual characteristics show that the average age of the respondents is 39 and the standard deviation is 11.199 years. According to the information, the average experience of the respondents is 13 years with the standard deviation of 7.230. There were 21 women $(42 \%)$ and 24 men(48\%) of all respondents and 5 people didn't answer this question.

2. Prioritizing items related to managers strategic thinking from respondents' point of view

In table 2, the independent variables effect on dependent variable and the prioritizing is mentioned. As you can see, among the items related to the managers strategic thinking, the variable of opportunities and threats recognition rate for internal-external environment, and the variable of opinion importance rate of client (within and out of organization) in decision making are the first and second priorities, respectively. The last priority is using the technological potential to achieve the organization goals. It can also be seen that the average of managers strategic thinking rate is 1.309 and shows a very low strategic thinking rate among respondents. 
Table2. Prioritizing Items Related to Strategic Thinking Effective on the Variable of Opportunity Exploitation from Respondents' Point of View

\begin{tabular}{|c|c|c|c|c|}
\hline Item & Average & $\begin{array}{l}\text { Standard } \\
\text { Deviation }\end{array}$ & $\begin{array}{l}\text { Changes } \\
\text { Coefficient }\end{array}$ & Priority \\
\hline $\begin{array}{l}\text { Opportunities and threats recognition } \\
\text { rate for internal-external environment }\end{array}$ & 1.80 & 0.456 & 0.253 & 1 \\
\hline $\begin{array}{l}\text { Opinion importance rate of client } \\
\text { (within and out of organization) in } \\
\text { decision making }\end{array}$ & 1.88 & 0.531 & 0.282 & 2 \\
\hline $\begin{array}{l}\text { The management department } \\
\text { importance as a partial of whole }\end{array}$ & 1.90 & 0.549 & 0.288 & 3 \\
\hline $\begin{array}{l}\text { Organizational unit under management } \\
\text { in main direction of organization }\end{array}$ & 2.00 & 0.581 & 0.290 & 4 \\
\hline $\begin{array}{l}\text { The role of external factors (general } \\
\text { policies of organization) to achieve } \\
\text { organization values }\end{array}$ & 1.92 & 0.577 & 0.300 & 5 \\
\hline $\begin{array}{l}\text { Communication with } \begin{array}{l}\text { other } \\
\text { organizational units to overcome } \\
\text { obstacles and problems }\end{array} \\
\end{array}$ & 1.94 & 0.592 & 0.305 & 6 \\
\hline $\begin{array}{l}\text { Using scientific method for making } \\
\text { decision in the organization under } \\
\text { management }\end{array}$ & 1.94 & 0.682 & 0.351 & 7 \\
\hline $\begin{array}{l}\text { Facing no obstacle on the way to } \\
\text { achieve goals }\end{array}$ & 1.86 & 0.700 & 0.376 & 8 \\
\hline $\begin{array}{l}\text { Using the physical facilities to achieve } \\
\text { the organization goals }\end{array}$ & 1.86 & 0.729 & 0.391 & 9 \\
\hline $\begin{array}{l}\text { Using the human resource to achieve } \\
\text { the organization goals }\end{array}$ & 1.86 & 0.731 & 0.393 & 10 \\
\hline Goals and desires clarity & 1.82 & 0.720 & 0.395 & 11 \\
\hline $\begin{array}{l}\text { Not leaving the organizational } \\
\text { problems of management to the } \\
\text { superior manager }\end{array}$ & 2.02 & 0.820 & 0.405 & 12 \\
\hline $\begin{array}{l}\text { Using creativity when make decisions } \\
\text { about the time opportunities }\end{array}$ & 1.56 & 0.644 & 0.412 & 13 \\
\hline $\begin{array}{l}\text { Using the technological potential to } \\
\text { achieve the organization goals }\end{array}$ & 1.92 & 0.862 & 0.448 & 14 \\
\hline Total & 1.309 & 0.218 & - & 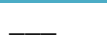 \\
\hline
\end{tabular}

Weighing the items include; from very low=1 to very high=5.

3. Items priorities related to the opportunity exploitation from respondents' point of view 
In table3, items priorities related to independent variables is shown. You can see, among items related to opportunity exploitation, the variables of studying rate and attention to favorable organization functions to make decision in management and the effectiveness of factors such as entrepreneur alertness, social network and personality characteristics on opportunity recognition were the first and the second priorities, respectively. The variable of investigating environmental threats and opportunities in public meetings was the last priority. It can also be observed that the average opportunity exploitation by managers is 1.852 that shows the opportunity exploitation among respondents is very low.

Table3. Items Priorities Related to the Opportunity Exploitation from Respondents' Point of View

\begin{tabular}{|c|c|c|c|c|}
\hline Item & Average & $\begin{array}{l}\text { Standard } \\
\text { Deviation }\end{array}$ & $\begin{array}{l}\text { Changes } \\
\text { coefficient }\end{array}$ & Priority \\
\hline $\begin{array}{l}\text { Studying rate and attention to favorable } \\
\text { organizations functions to make } \\
\text { decision in management }\end{array}$ & 1.90 & 0.505 & 0.265 & 1 \\
\hline $\begin{array}{l}\text { The effectiveness of factors such as } \\
\text { entrepreneur alertness, social network } \\
\text { and personality characteristics on } \\
\text { opportunity recognition }\end{array}$ & 1.94 & 0.550 & 0.283 & 2 \\
\hline $\begin{array}{l}\text { Exploiting past opportunities to } \\
\text { formulate goals }\end{array}$ & 1.96 & 0.570 & 0.290 & 3 \\
\hline $\begin{array}{l}\text { Visibility of using employees ideas in } \\
\text { organizations under management }\end{array}$ & 1.94 & 0.586 & 0.302 & 4 \\
\hline $\begin{array}{l}\text { Belief in relation between organization } \\
\text { current point with previous performance }\end{array}$ & 2.08 & 0.634 & 0.304 & 5 \\
\hline $\begin{array}{l}\text { Necessity of attention to the values } \\
\text { which make opportunity for the } \\
\text { customers }\end{array}$ & 1.88 & 0.640 & 0.340 & 6 \\
\hline $\begin{array}{l}\text { Creative hypothesizing possibility at } \\
\text { workplace }\end{array}$ & 1.76 & 0.657 & 0.373 & 7 \\
\hline $\begin{array}{llll}\text { Welcoming employees } & \text { ideas in } \\
\text { organization } & & \end{array}$ & 1.98 & 0.742 & 0.374 & 8 \\
\hline $\begin{array}{l}\text { Suitable environmental conditions to } \\
\text { test creative hypothesis }\end{array}$ & 1.82 & 0.691 & 0.379 & 9 \\
\hline $\begin{array}{l}\text { Positive approach towards changes as a } \\
\text { tool to discover new opportunities }\end{array}$ & 1.82 & 0.693 & 0.380 & 10 \\
\hline $\begin{array}{l}\text { Exploiting the relation between past, } \\
\text { now and future to create value }\end{array}$ & 1.82 & 0.720 & 0.395 & 11 \\
\hline $\begin{array}{lcr}\text { Environmental } & \text { changes effect on } \\
\text { organizational } & \text { activities } & \text { under }\end{array}$ & 1.73 & 0.700 & 0.404 & 12 \\
\hline
\end{tabular}




\begin{tabular}{|l|l|l|l|l|}
\hline management & & & & \\
\hline $\begin{array}{l}\text { Belief in relation between the current } \\
\text { strong points of organization with the } \\
\text { past performance }\end{array}$ & 1.68 & 0.683 & 0.406 & 13 \\
\hline $\begin{array}{l}\text { Investigating environmental threats and } \\
\text { opportunities in public meetings }\end{array}$ & 1.70 & 0.953 & 0.560 & 14 \\
\hline Total & 1.852 & 0.271 & - & - \\
\hline
\end{tabular}

Weighing the items include; from very low=1 to very high=5.

4. Independent variables correlation with the variable of opportunity exploitation

According to table 4, investigating the correlation coefficient shows; generally, the relation of individual factors such as experience background and age with the exploitation variable is not significant. The findings also show; generally, the relation of strategic thinking variable with the opportunity exploitation variable is positive and significant at the level of $1 \%$. $(r=0.439, p=0.004)$. it means If the managers strategic thinking is in a better situation, the opportunity exploitation will be more. Moreover, according to the table 5, the findings show that among the items related to strategic thinking variable, the relation between the variable of clients' opinion importance in decision making, using the human resource potential to achieve the organization goal and using technology to achieve organization goals with the dependent variable is positive and significant at the level of $5 \%$. The relation between the variable of not leaving the organizational problems of management to the superior manager with the dependent variable is positive and significant at the level of $1 \%$. There's no significant relation between other items related to managers' strategic thinking and dependent variable.

Table 4. Pearson Correlation Coefficient of Independent Variables with Opportunity Exploitation Variable

\begin{tabular}{|c|c|c|c|}
\hline Variable & Test type & $\begin{array}{l}\text { Correlation } \\
\text { Coefficient }\end{array}$ & Significance level \\
\hline Age(year) & Pearson & -0.108 & 0.469 \\
\hline Experience (year) & Pearson & 0.074 & 0.623 \\
\hline $\begin{array}{c}\text { Managers Strategic } \\
\text { Thinking }\end{array}$ & Pearson & 0.439 & $0.004 *$ \\
\hline
\end{tabular}

Correlation at the level of $1 \%$ is significant. $(\mathrm{p} \leq 0.01)$

Table5. Spearman Correlation Coefficients of Item Related to Strategic Thinking with Variable of Opportunity Exploitation

\begin{tabular}{|c|c|c|c|}
\hline Variable & Test type & $\begin{array}{l}\text { Correlation } \\
\text { coefficient }\end{array}$ & Significance level \\
\hline Opportunities and threats recognition & Spearman & 0.086 & 0.571 \\
\hline
\end{tabular}




\begin{tabular}{|c|c|c|c|}
\hline rate for internal-external environment & & & \\
\hline $\begin{array}{l}\text { Opinion importance rate of client } \\
\text { (within and out of organization) in } \\
\text { decision making }\end{array}$ & Spearman & $0.352^{*}$ & 0.018 \\
\hline $\begin{array}{l}\text { The management department importance } \\
\text { as a partial of whole }\end{array}$ & Spearman & 0.244 & 0.102 \\
\hline $\begin{array}{l}\text { Organizational unit under management } \\
\text { in main direction of organization }\end{array}$ & Spearman & 0.268 & 0.071 \\
\hline $\begin{array}{l}\text { The role of external factors (general } \\
\text { policies of organization) to achieve } \\
\text { organization values }\end{array}$ & Spearman & -0.008 & 0.960 \\
\hline $\begin{array}{l}\text { Communication } \begin{array}{l}\text { with } \\
\text { organizational units } \\
\text { obstacles and problems }\end{array}\end{array}$ & Spearman & 0.075 & 0.622 \\
\hline $\begin{array}{l}\text { Using scientific method for making } \\
\text { decision in the organization under } \\
\text { management }\end{array}$ & Spearman & & \\
\hline $\begin{array}{l}\text { Facing no obstacle on the way to } \\
\text { achieve goals }\end{array}$ & Spearman & 0.088 & 0.555 \\
\hline $\begin{array}{l}\text { Using the physical facilities to achieve } \\
\text { the organization goals }\end{array}$ & Spearman & 0.107 & 0.475 \\
\hline $\begin{array}{l}\text { Using the human resource to achieve the } \\
\text { organization goals }\end{array}$ & Spearman & $0.321^{*}$ & 0.028 \\
\hline Goals and desires clarity & Spearman & 0.093 & 0.534 \\
\hline $\begin{array}{l}\text { Not leaving the organizational problems } \\
\text { of management to the superior manager }\end{array}$ & Spearman & $0.452 * *$ & 0.001 \\
\hline $\begin{array}{l}\text { Using creativity when make decisions } \\
\text { about the time opportunities }\end{array}$ & Spearman & $0.294^{*}$ & 0.047 \\
\hline $\begin{array}{l}\text { Using the technological potential to } \\
\text { achieve the organization goals }\end{array}$ & Spearman & 0.081 & 0.589 \\
\hline
\end{tabular}

*Correlation at the level of $1 \%$ is significant. $(\mathrm{p} \leq 0.01)$

${ }^{*}$ Correlation at the level of $5 \%$ is significant. $(p \leq 0.05)$

5. The average ranking of female managers in comparison with male managers based on opportunity exploitation

According to the result from Man Whitney test, there's no significance difference between male and female managers in opportunity exploitation. Therefore, male and female managers exploit the 
opportunities identically and it shows that the gender variable has no significance effect on opportunity exploitation.

Table6. Male Managers Based on Opportunity Exploitation- Man Whitney Test

\begin{tabular}{|l|l|l|l|l|}
\hline Variable & Groups & $\begin{array}{l}\text { Ranking } \\
\text { Average }\end{array}$ & Statistics z & Significance level \\
\hline $\begin{array}{l}\text { Opportunity } \\
\text { Exploitation }\end{array}$ & Men & 21.57 & 0.038 & 0.970 \\
\cline { 2 - 5 } & Women & 21.43 & & \\
& & & & \\
\hline
\end{tabular}

\section{Discussion and Conclusion}

Organizations don't live in the vacuum. They work in an environment which forms their behavior and structure. The changes and their speed are the most important thing in the environment. In today's chaotic world, successful managers are those who are able to identify and exploit the opportunities. As strategic thinking includes punctual recognition of competition and finding the opportunities that other competitors are not aware of, the effect of managers strategic thinking was investigated in this study.

At first, researchers investigated the strategic thinking of technical managers of the travel and tourism agencies and companies in Tehran. Results show that these managers are at a low level of strategic thinking and their strategic thinking level is 1.309. Among the items about the managers strategic thinking, the variable of opportunities and threats recognition rate for internal-external environment, and the variable of opinion importance rate of client (within and out of organization) in decision making are the first and second priorities, respectively. The last priority is using the technological potential to achieve the organization goals. After studying strategic thinking level, the opportunity exploitation by the managers was tested. The result show that the opportunity exploitation by the managers has been low. Finally, the findings show that generally, the relation of strategic thinking variable with the opportunity exploitation variable is positive and significant at the level of $1 \%$. It means If the managers strategic thinking is in a better situation, the opportunity exploitation will be better. Moreover, the findings show that among the items related to strategic thinking variable, the relation between the variable of clients' opinion importance in decision making, using the human resource potential to achieve the organization goal and using technology to achieve organization goals with the dependent variable is positive and significant at the level of 5\%. The relation between the variable of not leaving the organizational problems of management to the superior manager with the dependent variable is positive and significant at the level of $1 \%$. There's no significant relation between other items related to managers' strategic thinking and dependent variable. According to the result of the study, the organization growth and survival in today's chaotic and competitive world, depends on opportunities identification and exploitation. According to the result of the study, the managers can exploit the existing opportunities when they have a strategic thinking. Last, the gender and opportunity exploitation was tested and the results showed that gender has no significant effect on opportunity exploitation. Therefore, female and male managers exploit the opportunities identically. 


\section{References}

[1] Abraham, Stan. (2005). Stretching strategic thinking. Strategy \& leadership, 33(5), 5-12.

[2] Amit, Raphael, \& Zott, Christoph. (2001). Value creation in e-business. Strategic management journal, 22(6-7), 493-520.

[3] Arayesh, Mohammad Bagher, Golmohammadi, Emad, Nekooeezadeh, Maryam, \& Mansouri, Abbas. (2017). The effects of organizational culture on the development of strategic thinking at the organizational level. International Journal of Organizational Leadership, 6(2), 261.

[4] Ardichvili, Alexander, Cardozo, Richard, \& Ray, Sourav. (2003). A theory of entrepreneurial opportunity identification and development. Journal of Business venturing, 18(1), 105-123.

[5] Balls, John Daniel. (2013). The Perceived Association of Merit Pay and Teacher Qualities in Two Middle Schools in a Southeastern State: Gardner-Webb University.

[6] Bonn, Ingrid. (2005). Improving strategic thinking: a multilevel approach. Leadership \& Organization Development Journal, 26(5), 336-354.

[7] Bouhali, Ratiba, Mekdad, Yousra, Lebsir, Hind, \& Ferkha, Linda. (2015). Leader roles for innovation: strategic thinking and planning. Procedia-Social and Behavioral Sciences, 181, 72-78.

[8] Casillas, Jose C, Moreno, Ana M, \& Barbero, Jose L. (2010). A configurational approach of the relationship between entrepreneurial orientation and growth of family firms. Family Business Review, 23(1), 27-44.

[9] Calabrese, Armando. Costa, Roberta.(2015). Strategic thinking and business innovation: Abduction as cognitive element of leaders' strategizing, Journal of Engineering and Technology Management.24-36

[10] Choi, Hyungwon, \& Pavelka, Norman. (2012). When one and one gives more than two: challenges and opportunities of integrative omics. Frontiers in genetics, 2, 105.

[11] Day, Jonathan D, \& Wendler, James C. (1998). The new economics of organization. The McKinsey Quarterly(1), 4-18.

[12] DEHGANI, A, Nahand, Ebrahim Salari, \& Ve Moghni, H. (2015). Identifying Components of Strategic Thinking and Their Role in Improving the Desicion-Making Process for Managers (Case Study: Organization fort he Protection of Consumers and Producers). World Essays Journal, $3(2), 150-160$.

[13] Goldman, Ellen F, \& Casey, Andrea. (2010). Building a culture that encourages strategic thinking. Journal of Leadership \& Organizational Studies, 17(2), 119-128.

[14] Haines, Stephen. (2016). The systems thinking approach to strategic planning and management: CRC Press.

[15] Heracleous, Loizos. (1998). Strategic thinking or strategic planning? Long range planning, 31(3), 481-487.

[16] Hitt, Michael A, Ireland, R Duane, Camp, S Michael, \& Sexton, Donald L. (2001). Strategic entrepreneurship: Entrepreneurial strategies for wealth creation. Strategic management journal, 22(6-7), 479-491. 
[17] Hsieh, Chihmao, Nickerson, Jack A, \& Zenger, Todd R. (2007). Opportunity discovery, problem solving and a theory of the entrepreneurial firm. Journal of Management Studies, 44(7), 1255-1277.

[18] Lehner, Othmar M, \& Kansikas, Juha. (2012). Opportunity recognition in social entrepreneurship: A thematic meta analysis. The Journal of Entrepreneurship, 21(1), 25-58.

[19] Liedtka, Jeanne M. (1998). Strategic thinking: can it be taught? Long range planning, 31(1), 120-129.

[20] Ramos-Rodríguez, Antonio-Rafael, Medina-Garrido, José-Aurelio, Lorenzo-Gómez, JoséDaniel, \& Ruiz-Navarro, José. (2010). What you know or who you know? The role of intellectual and social capital in opportunity recognition. International Small Business Journal, 28(6), 566582.

[21] Robinson, Deborah J. (2012). A comparative, holistic, multiple-case study of the implementation of the Strategic Thinking Protocol@ and traditional strategic planning processes at a Southeastern university: Florida Atlantic University.

[22] Schaper, Michael T, Volery, Thierry, Weber, Paull C, \& Gibson, Brian. (2014). Entrepreneurship and small business.

[23] Shepherd, Dean A. (2016). Thinking Entrepreneurially to Identify Research Opportunities The Aspiring Entrepreneurship Scholar (pp. 7-23): Springer.

[24] Short, Jeremy C, Ketchen Jr, David J, Combs, James G, \& Ireland, R Duane. (2010). Research methods in entrepreneurship: Opportunities and challenges. Organizational Research Methods, 13(1), 6-15.

[25] Simon, Gregory L, Bumpus, Adam G, \& Mann, Philip. (2012). Win-win scenarios at the climate-development interface: Challenges and opportunities for stove replacement programs through carbon finance. Global Environmental Change, 22(1), 275-287.

[26] Tang, Jintong, Kacmar, K Michele Micki, \& Busenitz, Lowell. (2012). Entrepreneurial alertness in the pursuit of new opportunities. Journal of Business Venturing, 27(1), 77-94.

[27] Tumasjan, Andranik, \& Braun, Reiner. (2012). In the eye of the beholder: How regulatory focus and self-efficacy interact in influencing opportunity recognition. Journal of Business Venturing, 27(6), 622-636.

[28] Zeidan, Susan, \& Bahrami, Shahin. (2011). Women entrepreneurship in GCC: A framework to address challenges and promote participation in a regional context. International Journal of Business and Social Science, 2(14), 100-107. 